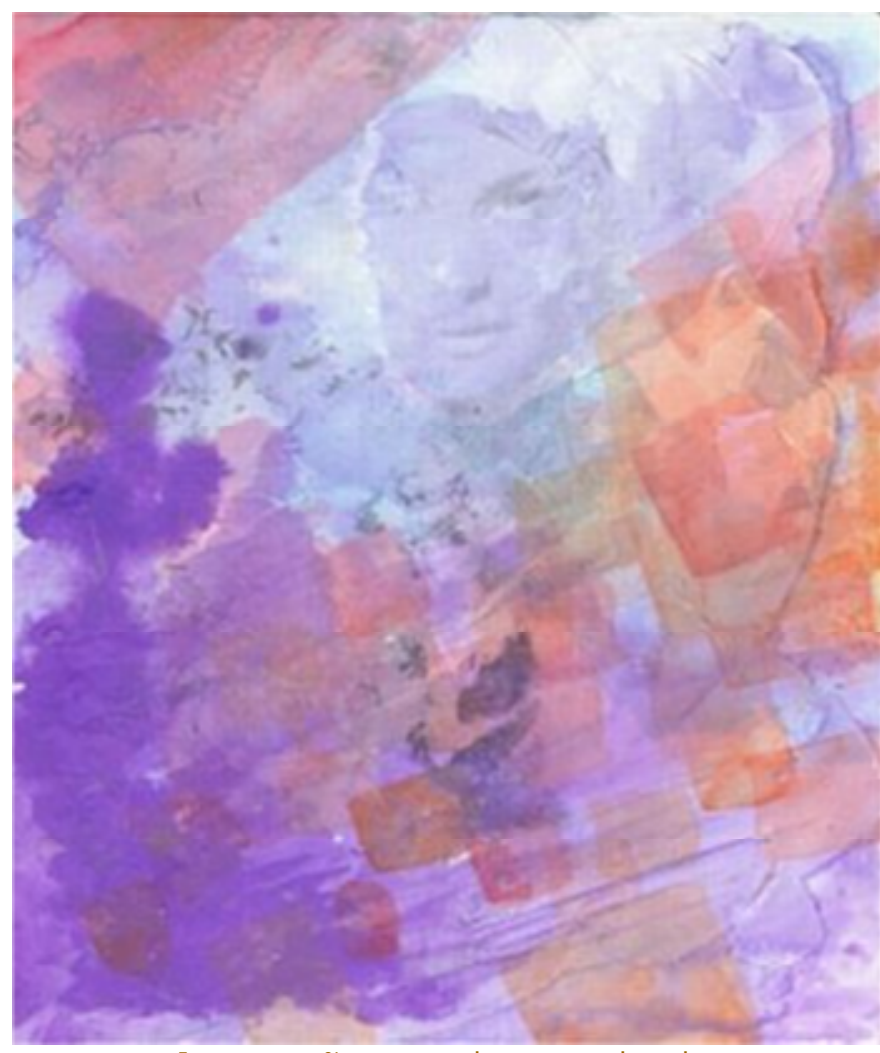

Ilustração Henrique Teixeira

\title{
FLEURY, Beth. Palavra possuída. Montes Claros: Ed. Orobó, 2005.
}

\section{Aline Medeiros Pinheiro e Nárli Machado}

Aline Medeiros Pinheiro e Nárli Machado são alunas da Faculdade de Letras da UFMG, coordenadoras do grupo Contar-te, monitoras no Projeto Leitura para todos, em Belo Horizonte e alunas de Iniciação Científica.

A poeta e jornalista paranaense Beth Fleury lançou no último dia 6 de dezembro, em Belo Horizonte, o livro de poesias Palavra possuída. Partindo de experiências pessoais e históricas, obtidas ao longo de viagens e deslocamentos pelo Brasil, a autora divide o livro em três momentos que, embora tenham como pano de fundo temáticas distintas, abordam questões relacionadas à complexa natureza dos homens e dos signos contemporâneos. 
Na primeira parte do livro, intitulada O fim e o começo, Beth retrata o universo feminino e a condição social da mulher, sendo a própria autora um exemplo dessa condição, no momento em que demonstra toda a expressividade feminina em suas relações de luta, amor e busca de outros horizontes. Tais elementos estão bastante explícitos em poemas como "Bordado", que é dedicado às mulheres dos anos 70, e "Beleza", que é uma homenagem à mãe da escritora.

Sob o título de Natureza das coisas, a segunda parte do livro problematiza questões sociais e políticas do Brasil e do mundo. De forma a provocar o leitor, Beth busca retratar a terrível realidade das guerras, da fome e da miséria, mas deixando sempre um "fio de esperança" capaz de tecer o futuro de homens e mulheres de nosso tempo.

Em Bordados e Armadilhas, terceiro momento do livro, a autora discorre sobre o ofício de poeta, bem como sobre a arte que constitui a construção da poesia. Esse espaço encontra-se fortemente relacionado com o título do livro, Palavra possuída, e ambos traduzem tudo aquilo que não pode ser apreendido apenas por palavras, enquanto mera descrição de fatos e da própria vida. Transformadas em bordados e armadilhas, as palavras transformam os lugares comuns e os elementos do cotidiano, dando sentido à existência de autores, leitores e textos.

A leitura desse livro nos remete ao que disse Roland Barthes sobre o ato de ler levantando a cabeça. Segundo o pensador, esse levantar a cabeça consiste no fato de lermos um livro, interrompendo com freqüência a leitura, não por desinteresse, mas por afluxo de idéias, excitações, associações. Sendo "irrespeitosa", pois interrompe o texto, essa leitura é também apaixonada, pois retorna ao texto e dele se nutre, conforme Barthes. É justamente isso que Palavra possuída provoca no leitor: uma constante atitude de reflexão, um incessante ato de ler levantando a cabeça. 